\title{
Evaluation of the proximate, mineral, phytochemical and amino acid composition of Bidens pilosa as potential feed/feed additive for non-ruminant livestock
}

\author{
Philip Cheriose Nzien Alikwe ${ }^{1, *}$, Elijah Ige Ohimain ${ }^{2}$, Soladoye Mohammed Omotosho ${ }^{3}$ \\ ${ }^{1}$ Animal Science Department, Niger Delta University, Yenagoa, Nigeria \\ ${ }^{2}$ Biological Sciences Department, Niger Delta University, Yenagoa, Nigeria \\ ${ }^{3}$ SMO Laboratory Consult, 5 Joyce B Shopping Complex, Ibadan, Nigeria
}

\section{Email address:}

agricbiochem2011@gmail.com (P. C.N. Alikwe), eohimain@yahoo.com (E. I. Ohimain)

\section{To cite this article:}

Philip Cheriose Nzien Alikwe, Elijah Ige Ohimain, Soladoye Mohammed Omotosho. Evaluation of the Proximate, Mineral, Phytochemical and Amino Acid Composition of Bidens Pilosa as Potential Feed/Feed Additive for Non-Ruminant Livestock. Animal and Veterinary Sciences. Vol. 2, No. 2, 2014, pp. 18-21. doi: 10.11648/j.avs.20140202.11

\begin{abstract}
Bidens pilosa are popular weeds in the South West Region of Nigeria which are self-propagated by glueing itself on farmer's dresses and animal's skin. Bidens pilosa leaf meal (BPLM) were analyzed to determine proximate nutrient content, amino acid composition, phytochemicals and mineral constituents. The protein content of the leafmeal from the plant is $15.86 \%$, These values are high compared to those for some common Nigerian weeds used as forage plants. Leaves had high percentage of crude fibre (18.13\%). Carbohydrates, lipid, moisture and ash contents were within the range expected for dry leafy vegetable. Five (5) essential amino acids were found in varying proportions in the protein of Bidens pilosa Leafmeal. The phytochemicals analyzed indicated the presence of tannins, alkaloids, saponins, phenols and glycoside in the BPLM were lower than the range of values reported for most vegetables. Hence may serve as a good source of feed or feed additive for non-ruminants such as pigs, rabbits and guinea pigs.
\end{abstract}

Keywords: Bidens Pilosa, Amino Acid, Nutrients, Phytochemicals, Weeds

\section{Introduction}

Bidens pilosa is a species in the plant family Asteraceae (Spanish needles, Farmer's needle) is considered a weed in some tropical habitats. However, in some parts of the world it is a source of food [1]. It is a small erect annual cosmopolitan herb common in all tropical and subtropical areas of the world.

Despite all its nutraceutical potentials, there is scanty information on the bioactive compounds, proximate, mineral and amino acid composition of this plant's leafmeal. Bidens pilosa leaf meal (BPLM) nutritional importance on man and his livestock has been ignored. No attention has been paid to this weed which contributes significantly to land security in some rural communities. Bidens pilosa grows very well in Nigeria for 9 months without irrigation. It's inclusion in the diets of broilers and other poultry birds and livestock may reduce cost of production. Cost of feed from the total cost of production in poultry is about 55.00 $75.20 \%$ in Nigeria [2]. However, utilization of (BPLM) in non-ruminant nutrition is not common in our environment. In an attempt to solve the aforementioned problem nonconventional locally available and relatively low cost and nutritionally rich forage meals are sourced for non-ruminant production.

Cheeke [3] reported that tropical forages are rich in protein, potassium, calcium and phosphorus, though high in indigestible fibre. Bidens pilosa can be harvested almost all year round in the tropical environment and it is rich in crude protein and minerals. The roots, leaves and seed have been reported to possess antibacterial, antidysenteric, anti-inflammatory, antimicrobial, antimalarial, diuretic, hepato-protective and hypotensive activities [4]. Phytochemically, the plant is rich in flavonoids, terpenes, phenylpropanoids, lipids, and benzenoids [5, 6]. There is paucity of information in the use of this plant in non-ruminant nutrition. Therefore, this study was undertaken to determine the proximate, amino acid, mineral constituents and phytochemicals profiles of this herb in furtherance to ascertaining it's potentials as a feed supplement or feed additive to non-ruminant livestock. 


\section{Materials and Methods}

Bidens pilosa leaves were collected from a farm site at Umunede located in Ika North East LGA of Delta State, Nigeria, cleaned and spread on the already cleaned laboratory bench for 5 days in the Animal Science Laboratory, Niger Delta University. The dried leaves were milled and a portion $(50 \mathrm{~g})$ of the powdered sample was processed for various parameters at the IAR\&T Biochemistry laboratory Ibadan according to the following procedures: The proximate analyses of the plant leaf were determined by the method described by AOAC, [7]. Buck scientific Atomic Absorption Spectrophotometer (AAS), model 210VGP, was used to metal analysis, while ascorbic acid method was used for phosphate analysis. Total phenolics were determined by method described by Mole and Waterman [8], Saponins by the spectrophometric method of Brunner as described by Akinmutimi [9], Alkaloids by gravimetric method of Harbone [10], Tannins was determined by method of Maga as described by Akinmutimi [9] and Phytate by Lucus and Markakas method as described by Akinmutimi and Anakebe [9]. All data were expressed as mean \pm SD and GraphPad Instat (Data set LSD) were used.

\section{Result}

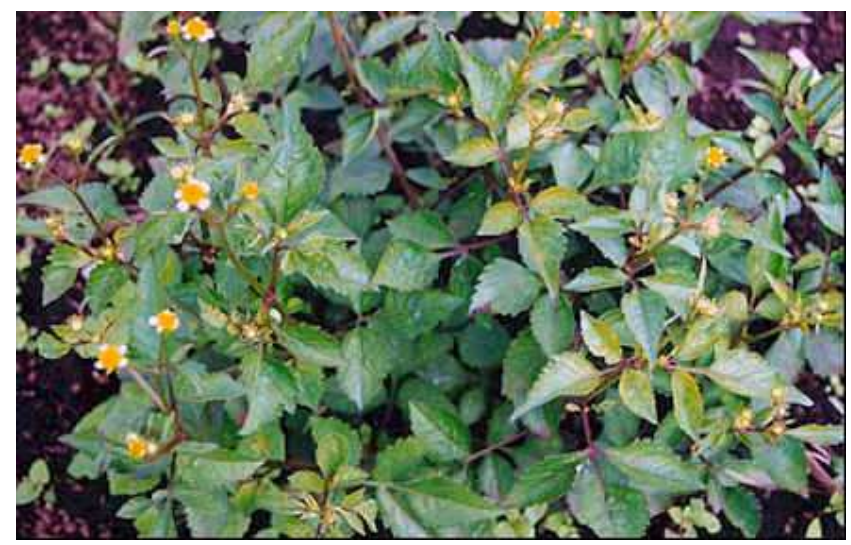

Fig 1. Bidens pilosa.

The results as shown in Table 1 indicate that Bidens pilosa leafmeal (BPLM) had Crude Protein of $15.86 \pm 1 \%$, ash 12.31. $\pm 0.07 \%$, Crude fiber $18.13 \pm 0.04 \%$. The macro/ micro elements observed in BPLM are Na: $0.54 \pm$ $0.3 \mathrm{mg} / 100 \mathrm{~g}$ Ca: $0.39 \pm 1.40 \mathrm{mg} / 100 \mathrm{~g}$ Mg: $0.23 \pm 0.46$ $\mathrm{mg} / 100 \mathrm{~g}, \mathrm{P}: .31 \pm 0.1 \mathrm{mg} / 100 \mathrm{~g}, \mathrm{~K}: 1.21 \pm 0.1 \mathrm{mg} / 100 \mathrm{~g} \mathrm{Cu}$ : $12.6 \pm 0.3 \mathrm{mg} / 100 \mathrm{~g}, \mathrm{Mn}: 22.0 \pm 0.01 \mathrm{mg} / \mathrm{kg}$, and $\mathrm{Zn}: 45.30 \pm$ $0.02 \mathrm{mg} / \mathrm{kg}$. Fe: $789.00 \pm 0.1 \mathrm{mg} / \mathrm{kg}$. The Amino acid constituent according to the analysis indicated the presence of Methionine: $0.54 \pm 0.2 \mathrm{mg} / 100 \mathrm{~g}$, Lysine: $1.07 \pm 0.5 \mathrm{mg}^{-}{ }^{100 \mathrm{~g}}$ among others. The phytochemicals found were Tannins, $0.08 \pm 0.23 \mathrm{mg} / 100 \mathrm{~g}$, Saponins $0.896 \pm 0.50 \mathrm{mg} / 100 \mathrm{~g}$, Phenols $0.206 \pm 0.10 \mathrm{mg} / 100 \mathrm{~g}$ and Alkaloids: $1.29 \pm 0.5 \mathrm{mg} / 100 \mathrm{~g}$.

Table 1. Proximate, Mineral, Phytochemical and Amino Acid Analysis of Bidens pilosa leaf meal.

\begin{tabular}{llllllll}
\hline Proximate Analysis & $\mathbf{g} / \mathbf{1 0 0 g}$ & Phytochemicals & $\mathbf{M g} / \mathbf{1 0 0 g}$ & Mineral & & Amino acid & g/100g \\
\hline Crude Protein & 15.86 & Alkaloid & 1.29 & $\mathrm{Na}$ & $0.54 \mathrm{mg} / 100 \mathrm{~g}$ & Methionine & 0.54 \\
Crude Fat & 7.49 & Saponin & 0.896 & $\mathrm{Ca}$ & $0.39 \mathrm{mg} / 100 \mathrm{~g}$ & Lysine & 1.07 \\
Crude Fibre & 18.13 & Phenol & 0.206 & $\mathrm{P}($ Total $)$ & $0.31 \mathrm{mg} / 100 \mathrm{~g}$ & Alanine & 1.34 \\
Ash & 12.31 & Glycoside & 0.383 & $\mathrm{~K}$ & $1.21 \mathrm{mg} 100 \mathrm{~g}$ & Cysteine & 0.289 \\
NFE & 49.11 & Tannins & 0.085 & $\mathrm{Mn}$ & $22.0(\mathrm{mg} / \mathrm{Kg})$ & Tryptophan & 0.69 \\
Dry Matter & 90.59 & & & $\mathrm{Cu}$ & $12.6(\mathrm{mg} / \mathrm{Kg})$ & & \\
Gross Energy & 3.456 & & & $\mathrm{Zn}$ & $45.3(\mathrm{mg} / \mathrm{Kg})$ & & \\
(Kcal-g) & & & $\mathrm{Mg}$ & $0.23 \mathrm{mg} / 100 \mathrm{~g}$ & \\
& & & $\mathrm{Fe}$ & $789(\mathrm{mg} / \mathrm{Kg})$ & \\
\hline
\end{tabular}

\section{Discussions}

The results obtained from proximate analysis of leaves of suggest that the herb can be ranked as carbohydrate rich leaves due to their relatively high carbohydrate content when compared with the other components of the leaves. The low moisture content of the leaves would hinder the growth of micro organisms and the storage life would be high [11].

The crude protein content of the leaves is $15.86 \%$ and it compares favourably with Heinsia crinita (14.7\%),Occimum gratisisimum and O.sanctum $16.27 \%$ and $16.38 \%$ [12] but are relatively low when compared with Amaranthus caudatus $(20.59 \%)$ [13, 14], cassava leaves (Manihot utilisima), 24.88\%, Piper Guineeses $29.78 \%$ and Talinum triangulare $31.00 \%$ [14].
The ash content is $12.31 \%$. The ash content of the leaves is lower than that of some leafy vegetables commonly consumed in Nigeria such as Talinum triangulare $(20.05 \%)$ and Occimum gratisismum(12.33\%) and Occimum $\operatorname{sanctum}(11.38 \%)$ [12]. It is however higher than some other vegetables such as Hibiscus esculentus (8.00\%) [14]. The ash content is a reflection of the mineral contents preserved in the food materials. The result therefore suggests a moderate deposit of mineral elements in the leaves [15]. The crude fibre content of $18.13 \%$ is high compared with Talinum triangulare (6.20\%), Piper guineeses (6.40\%), Corchorus olitorius (7.0\%), bitter leaves (Vernonia amygdalina), 6.5\% [14], but similar to that of Occimum gratisismum $(17.22 \%)$ and Occimum sanctum $(17.54 \%)$ [12]. This may disqualify BPLM as a feed source for poultry but may be useful as rabbit feed since rabbits are pseudo-ruminants Indira [19] defined dietary fiber as the edible parts of plants or analogous carbohydrates 
that are resistant to digestion and absorption in the human small intestine with complete or partial fermentation in the large intestine.

The term phytochemicals refer to those substances found in plant foods that is not an essential nutrient but may have health promoting properties. The phytochemical component studied revealed that BPLM has low amount of Tannin, Saponins, Phenols, Alkaloids, and Glycoside. which are known to exhibit medicinal and physiological activity [20] and may serve effectively as feeding stuff or feed additive for livestock and as medicinal herbs to man According to Kawo et al [21], phytochemical components are responsible for both pharmacological and toxic activities in plants. These metabolites are said to be useful to a plant itself but can be toxic to animals including man if consumed in large quantities. They also show tumour inhibiting activity on animals [14].

From the above results, these leaves may serve as a constituent of livestock/human diet supplying the body with minerals, protein and energy. The presence of secondary plant products in the leaves of Bidens pilosa that are biologically important e.g. saponins and phenols contributes to its medicinal value thus they can be potential sources of useful drugs/feed additives.

Among the minerals analyzed in the herb, potassium was the most abundant $(1.21 \mathrm{mg} / 100 \mathrm{~g})$ element, and this is in agreement with many reports that potassium is the most abundant mineral in Nigerian agricultural products [22]. Potassium helps to maintain body weight and regulate water and electrolyte balance in the blood and tissues [23]. The calcium content was determined to be $0.39 \mathrm{mg} / 100 \mathrm{~g}$. Calcium helps in the regulation of muscle contraction required by young animals and foetuses for bones and teeth development [24]. The concentration of sodium in the sample was also low $(0.54 \mathrm{mg} / 100 \mathrm{~g})$, and supports the claim by the natives that the herb is useful in the treatment of heart related diseases. Excess sodium consumption leads to hypertension [23]. The phosphorus content of the vegetable was $0.31 \mathrm{mg} / 100 \mathrm{~g}$. This figure is lower than that reported on other herbs. Phosphorus plays a vital role in normal kidney functioning and transfer of nerve impulse. The concentration of zinc in the vegetable was given as $45.30 \mathrm{mg} / 1000 \mathrm{~g}$. Zinc is said to be an essential trace element for protein and nucleic acid synthesis and normal body development [25]. Zinc also stimulates the activity of vitamins, and the formation of red and white blood cells [26]. Zinc plays a role in improving male fertility. The iron content of the herb was given as $789 \mathrm{mg} / 1000 \mathrm{~g}$, and compares favourably with other herbs. Iron is said to be an important element in the diet of monogastrics to prevent anaemia and other related diseases [27]. The magnesium content of the leafmeal was found to be $0.23 \mathrm{mg} / 100 \mathrm{~g}$.Magnesium plays fundamental roles in most reactions involving phosphate transfer. Magnesium is essential in skeletal tissue metabolism and neuromuscular transmission. Magnesium is necessary as an activator of many enzyme systems, particularly those concerned with carbohydrate metabolism [28]. It is believed to be essential in the structural stability of nucleic acids. It plays a significant role in the intestinal absorption of electrolyte in the body. Its deficiency in man includes severe diarrhoea, persistent migraines and neuromuscular hyperirritability in chickens [28, 29]. Copper occurred at a concentration of $12.60 \mathrm{mg} / 1000 \mathrm{~g}$ in this plant, and this value is well below the concentration that is said to be critical $(1.5-5.0 \mathrm{mg} / 100 \mathrm{~g})$ in plant materials [30]. The concentration of manganese in the plant sample was determined to be $22.0 \mathrm{mg} / 1000 \mathrm{~g}$. Consumption of manganese-containing foods is believed to support the immune system. Manganese regulates blood sugar levels, the production of energy and cell reproduction. Deficiency in manganese may result in birth defects if an expectant animal do not get enough of this important element [31].

\section{Conclusion}

This study has shown the proximate, phytochemical, mineral and amino acid compositions of Bidens pilosa leafmeal as a balanced and rich source of macro- and micronutrients. The phytochemical profile shows the potential medicinal usefulness of the plant as an agent capable of ameliorating a myriad of diseases, in man and livestock. The leaf can be seen as a potential source of useful items for food/feed and feed additive and drugs formulation. Further field/laboratory work of using different monogastrics for biological testing is ongoing. The issue of replacing/substituting another plant product will be looked into in our biological research work

\section{Acknowledgements}

The authors thank Tariwari Angaye for formatting the manuscript.

\section{References}

[1] G.J.H. Grubben, and O.A. Denton, Plant Resources of Tropical Africa 2. Vegetables. PROTA Foundation, Wageningen; Backhuys, Leiden;CTA, Wageningen 2004.

[2] J.O. Atteh, Principles and practice of livestock feed manufacturing, Adlek Printers 64,Sabo-line Ilorin, 2002.

[3] P.R. Cheeke, The significance of fibre in rabbit nutrition, J. Appl Rabbit Res. 2004, 61(1):53-55.

[4] B. Mvere, Bidens pilosa L. Record from Protabase. Grubben, G.J.H. \& Denton, O.A. (Editors). PROTA (Plant Resources of Tropical Africa / Ressources végétales de l'Afrique tropicale), Wageningen, Netherlands, 2004.

[5] J.S. Chang, L.C. Chiang, C.C. Chen and T.T. Liu, Am. J. Clin. Med. 29, 303 cited by Adedapo, A, Jimoh, F and Afolayan A (2011) Comparison of the nutritive value and biological activities of the acetone, methanol and water extracts Of the leaves of Bidens pilosa and Chenopodium album Acta Poloniae Pharmaceutica ñ Drug Research, Vol. 68 No. 1 pp. 83ñn92, 2001. 
[6] C. Abajo, M.A. Bofill, J. del Campos, M.A. Mandez, Y. Gonzalez, M. Mitjans and M.P Vinardell, J. Ethnopharmacol. 93, 319 cited by Adedapo, A, Jimoh, F and Afolayan A (2011) Comparison of the nutritive value and biological activities of the acetone, methanol and water extracts Of the leaves of Bidens pilosa and chenopodium album Acta Poloniae Pharmaceutica ñ Drug Research, Vol. 68 No. 1 2004, pp. 83ñ92, 2004.

[7] AOAC, Official methods of analysis. Association of Official Analytical Chemists, Washington D.C. 15th Ed. 1990.

[8] S. Mole and P.G Waterman, A critical analysis of techniques for measuring tannin and phenolics for ecological studies, Oecologia. 72:137-14, 1978.

[9] A.H. Akinmutimi, and O.C. Anakebe.. "Performance of Weaner Rabbits Fed Graded Levels of Yam and Sweet Potato Peel Meal in Place of Maize-Based Diet". Pakistan Journal of Nutrition. 7(5):700-704, 2008

[10] J. Harbone, Photochemical Methods: A Guide to Modern Techniques of Plant Analysis. Chapman \& Hall, London, 1998.

[11] E.I Adeyeye and O.O. Ayejuyo, Chemical composition of Cola accuminata and Garcina Kola seeds grown in Nigeria. Int. J. Food Sci. Nutr., 45: 223-230, 1994.

[12] P.C.N. Alikwe, E.I. Ohimain S.M. Omotosho, and O.O. Afolabi, Proximate, Mineral, Phytochemical and Amino Acid Composition of Ocimum gratissimum and Ocimum sanctum, Continental J. Animal and Veterinary Research (C) Wilolud Journals, 5 (1): 22 - 30, ISSN: 2141 http://www.wiloludjournal.com doi:10.5707/cjavres, 2013.

[13] E,N, Etuk, M.N. Bassey, U.O. Umoh and E.G. Inyang, Comparative nutritional studies on three Local varieties of Heinsia crinita. Plant Varieties and Seeds, 11: 151-158, 1998.

[14] A.A. Akindahunsi and S.O. Salawu, Phytochemical Screening and nutrient-antinutrient composition of selected tropical green leafy vegetables. Afr. J. Biotech., 4: 497-501, 2005.

[15] B.S. Antia, E.J. Akpan, P.A. Okon and I.U. Umoren, Nutritive and Anti-Nutritive Evaluation of Sweet Potatoes (Ipomoea batatas) Leaves. Pak. J. Nutr., 5: 166-168, 2006.

[16] M. Indira, Dietary Fiber An Essential Macronutrient, Lecture delivered at the 3rd National Seminar on
Phytochemicals and Nutrition organized by Centre for Development of Science and Technology, Thrissur and Department of Botany, 2009, Fatima Mata National College, Kollam.

[17] L.A. Sofowora, Medicinal plants and traditional medicine in Africa. Spectrum Books Ltd, Ibaban, pp. 55-71, 1993.

[18] A.H. Kawo, B.A. Abdullahi, Z.A. Gaiya, A. Halilu, M. Dabai and M.A Dakare, M.A, Preliminary phytochemical screening, proximate and elemental composition of Moringa oleifera LAM seed powder. Bayero Journal of pure and applied science, Vol 2 (1): 96-100, 2009.

[19] Afolabi, G., Oluwade, A., \& Tunde, O. (1995). Estimation of Proximate and Mineral Composition of SomeTropical Crops, African Agricultural Journal, 21, 103, 1995.

[20] NRC, National Research Council Recommended Dietary Allowance, National Academy Press,Washington D. C, 1998.

[21] L. Margaret, and B. Vickery Plant Products of Tropical Africa. Macmillan in College ed. London, 1997.

[22] U, Melaku, E.W. Clive, and F Habtamon, Content of zinc, Iron, Calcium and Their Absorption Inhibitors in Ethiopia, Journal of Food Composition Analysis, 18, 803-817.http://dx.doi.org/10.1016/j.jfca.2004.09.008, 2005.

[23] B. Claude, and S. Paule, S, The Manual of Natural Living (1st ed.). Biddles Ltd., Guildford, Surrey, pp.98-101, 1979.

[24] E.A Oluyemi, A.A. Akilua, A.A. Adenuya and M.B Adebayo, Mineral Contents of Some Commonly Consumed Nigerian Foods. Science Focus, 11(1), 153-157, 2006.

[25] J.M Olomu, Monogastric Animal Nutrition, Principles and Practice $2^{\text {nd }}$ Edition St Jackson Publishing, Benin City Nigeria pp. 55-69, 2011.

[26] L.J, Appel, L. J, Nonpharmacologic Therapies that Reduce Blood Pressure. A fresh Perspective, Clin.Cardiol, 1111-1115, 1999.

[27] R. Miroslav and N.B. Vladimir, Practical Environmental Analysis, UK: Royal Society of Chemistry, 1999, pp. 284-314 \& 357.

[28] B.A. Anhwange, V.O Ajibola, and S.J Oniye, Chemical Studies of the Seeds of Moringa oleifera and Deuterium microcarpum. Journal of Biological Sciences, vol VI, 711-715 .http://dx.doi.org/10.3923/jbs.2004.711.715, 2004. 